\title{
Transformational potential of networked information
}

\author{
By Noreen Alldredge and Thomas G. Kirk
}

\section{A Coalition for Networked Information report}

$\mathbf{T}$ he Task Force of the Coalition for Networked Information (CNI) met in Washington, D.C., on November 19-20. With over 350 attendees the conference was the largest coalition meeting held thus far. The next meeting will be March 22-23, 1993, in San Francisco.

The conference centered around the theme "The Transformational Potential of Networked Information," and suggested a number of issues which academic librarians need to think about and address. Instead of trying to summarize the conference, much of which was tentative and in formative stages of development, your ACRL representatives chose to reflect the conference in a series of questions. The questions are suggested as starting points; they may provoke more questions than answers at this point. If they seem global or premature we suggest readers pursue the literature for more detail. At the end of this column there are some suggestions for access to the literature.

\section{Questions, comments?}

Feel free to contact ACRL's representatives to the coalition with your comments or questions via all modes of communication:

Noreen Alldredge, Dean of Libraries, Montana State University, Bozeman, MT 59717-0332; voice: (406) 994-3119; fax: (406) 994-2851; e-mail: alldredge/lib@renne. lib.montana.edu.

Thomas G. Kirk, College Librarian, Berea College, Berea, KY 40404; voice: (606) 986-9341, ext. 5266; fax: (606) 986-9494; email: bertgk@ukpr.uky.edu
- Are individual academic libraries working with their local congressional representatives to ensure that they know how the networked environment is already affecting the distribution of information?

- Does each academic library have staff who are assigned the responsibility for developing their expertise in aspects of networked and electronic information?

- Has a program been developed to keep faculty at all levels of sophistication and interest informed and prepared to use the advancing capabilities of networking?

- Are academic libraries working with museums and other units on campus that have educational resources to bring access to those resources into the networked environment?

- Are academic libraries developing plans to provide electronic access to archival collections or indexes to such collections? Are mechanisms for the electronic capture and transmission of important archival materials being developed?

- Does the campus have a plan to upgrade hardware and telecommunications infrastructure so that larger and larger message units and multimedia information can be received?

\section{Networked information resources}

Those who want more information on CNI and/ or wish to obtain CNI documents can send an e-mail message to INFO@CNI.ORG and a staff member will respond. Some documents can be anonymously FTP'd from FTP.CNI.ORG once you have received a list of available documents. Joan Lippincott, assistant executive director of CNI, can be contacted at JOAN@CNI.ORG or (202) 232-2466 to answer harder questions.

Thomas $G$. Kirk is college librarian at Berea College; Noreen Alldredge is dean of libraries at Montana State University 